\title{
Chicken $\mathrm{HH} 27$
}

\section{Frontal view}

Frontal transparant

\section{Septum left}

\section{Septum right}

\section{Cranial view}

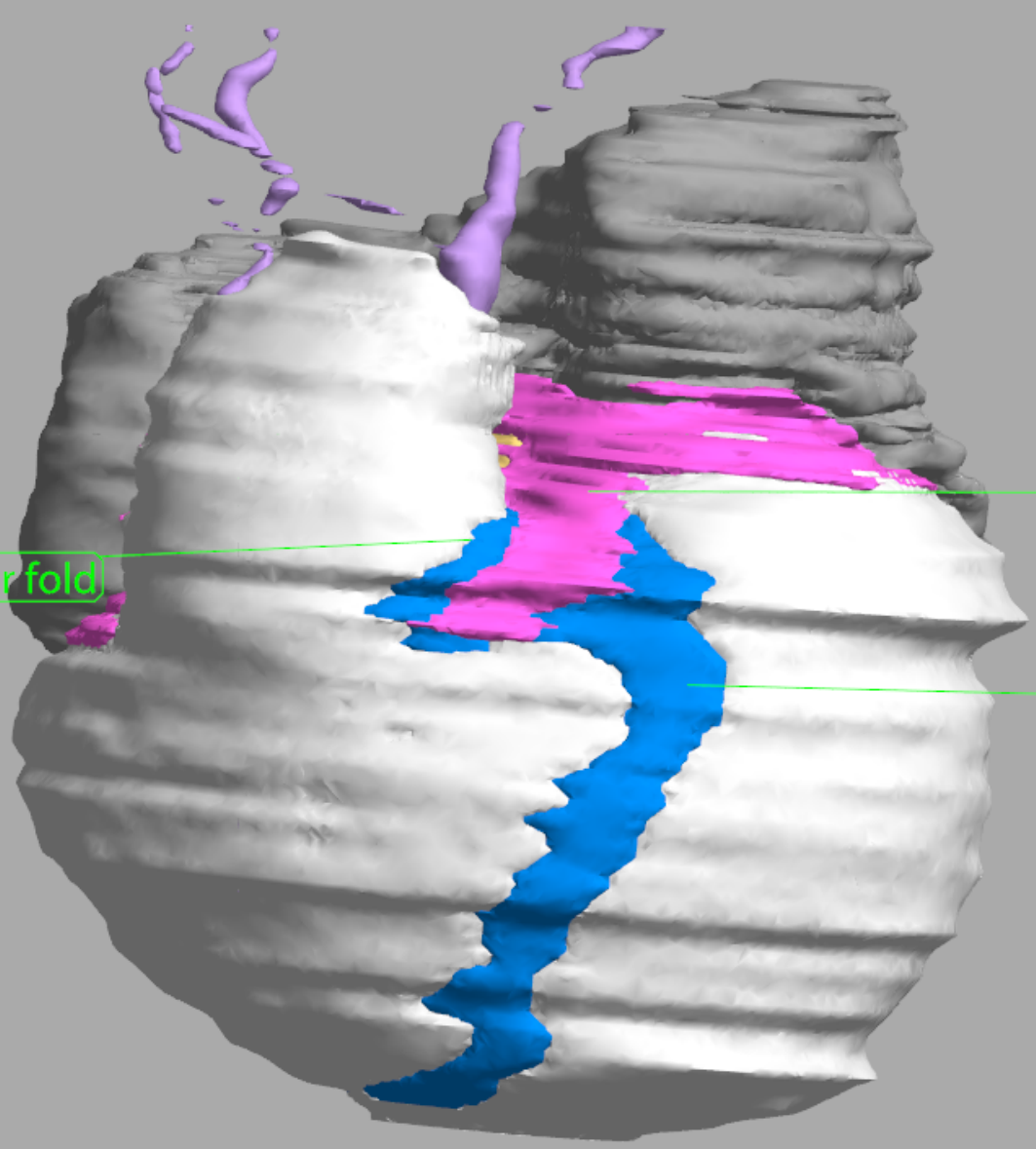

